\title{
СЕМАНТИЧКА АНАЛИЗА РОМАНИЗАМА ИЗ НАРОДНИХ ГОВОРА ЦРНЕ ГОРЕ**
}

\begin{abstract}
У раду је приказана семантичка анализа позајмљеница романског порекла посведочених у народним говорима Црне Горе. Романизми су распоређени у лексичко-семантичке групе које су формиране на основу Баковог списка семантичких поља, уз извесне измене које захтева специфичност дијалекатског материјала. Циљ овог истраживања је да се добије јаснија слика у којим је сферама свакодневног живота утицај романских језика и дијалеката био највидљивији, као и који су могући разлози који су до тога довели.

Кључне речи: српски (српско-хрватски) језик, лексикографија, лексичко-семантичка анализа, романизам.
\end{abstract}

Увод

Прецизно дефинисање термина романизам јесте полазишна тачка при сваком истраживању утицаја романског елемента на српско-хрватске говоре. На његово одређење утиче првенствено одговор на питање да ли се под романизме убрајају искључиво директне позајмљенице или и индиректне. ${ }^{1}$ У овом раду под термином романизам подразумевају се речи које су из неког од романских језика или дијалеката ушле директно у неромански језик или дијалекат.

Имајући у виду да је у питању вишевековни утицај многобројних језика и дијалеката који припадају романској породици, јасно је да се ради о различитим слојевима и различитим старинама позајмљеница романског

\footnotetext{
*tesicana@gmail.com

** Овај чланак је настао као резултат рада на пројекту бр. 178007 „Етимолошка истраживања српског језика и израда Етимолошког речника српског језика”, који у целини финансира Министарство просвете и науке Републике Србије.

${ }^{1}$ Пример индиректних романизама јесте музичка терминологија, која је, иако крајњег италијанског порекла, ушла у српско-хрватске говоре преко немачког језика (в. Клајн 1998: 75).
} 
порекла. Основна подела романизама на основу хронолошке стратификације јесте она на старији и новији слој. У старији слој убрајају се позајмљенице из вулгарнолатинског, тј. латинско-романског (до VIII-IX в.), позајмљенице из далматског (од IX до XII-XIII в., на Крку и у Дубровнику и дуже) и венецијанизми, тј. позајмљенице из колонијалног венецијанског (од ХІІІ в. надаље). ${ }^{2}$ Позајмљенице из различитих дијалеката италијанског језика (нпр. фурланског) и из италијанског књижевног језика, тзв. тосканизми, заједно са позајмљеницама из других романских језика (нпр. румунског) чине новији слој романизама у српско-хрватским говорима.

За потребе овог истраживања анализирано је преко шест стотина позајмљеница романског порекла потврђених у народним говорима Црне Горе. Материјал за корпус је ексцерпиран из речника и збирки речи које обрађују лексику ових говора. У корпус су увршћене позајмљенице романског порекла посведочене у свим приморским и континенталним говорима Црне Горе, који припадају зетско-сјеничком и источнохерцеговачком дијалекту. У анализирани материјал укључени су и романизми из одређених говора зетско-сјеничког дијалекта који су претходно били ексцерпирани за потребе израде докторске дисертације (в. Тешић 2016). Проширење корпуса на читаву територију Црне Горе било је неопходно да би се могао стећи прави увид у питање семантичке раслојености позајмљеница романског порекла у народним говорима Црне Горе.

Материјал из зетско-сјеничких говора Црне Горе ексцерпиран је из следећих речника и збирки речи: Башановић Чечовић 2010, Боричић 2002, Јокић 2012, Липовац Радуловић 1981, Липовац Радуловић 1997, Милетић 1940, Оташевић 2012, Пешикан 1965, Поповић/Петровић 2009, Петровић и др. 2013, Стијовић 1996, Ћупић 1977, Ћупић Д./Ћупић Ж. 1997, Хаџић 2003. У раду су коришћени речници и збирке речи који бележе лексику источнохерцеговачког дијалекта у народним говорима Црне Горе: Вујичић 1995, Гаговић 2004, Ђоковић 2010, Копривица 2006, Мусић 1972, Ристић 2010, Станић 1990-1991.

\section{Претходна изученост проблематике}

Утицаји романских језика и дијалеката на српско-хрватске говоре били су до сада предмет великог броја радова и студија, а неки од њих су укључивали и семантички аспект ових позајмљеница (нпр. Гачић 2007, Плишко 2009, Спицијарић 2009, Галовић 2013). Ови су се радови заснивали првенствено на грађи из далматинских и истарских говора.

Специфичне значењске карактеристике романизама из говора Црне Горе описане су у неколико радова који су се бавили том проблематиком (нпр. Драшковић 1977, Вукмановић Мојсиловић 1994, Тешић 2014а, Тешић 2014б). Међутим, у већини њих обрађиване су појединачне речи или специ-

\footnotetext{
2 Детаљније о хронолошкој стратификацији старијих слојева романизама в. Текавчић 1976 , Лигорио 2014.
} 
фичне лексичко-семантичке групе. Из тог су разлога у овом раду анализирани романизми из свих говора континенталне и приморске Црне Горе уз шири захват семантичке анализе, са циљем да се добије потпунији увид у јачину утицаја романских језика и дијалеката на народну лексику и домене у којима је он најприметнији.

\section{Историјат друштвено-историјских прилика}

Алоглотску лексику романског порекла у говорима Црне Горе неопходно је сагледати кроз историјске околности овог подручја које, са становишта овог истраживања, подразумевају два периода контаката између романског и словенског становништва - најпре, њихов суживот након доласка Словена у VII веку на Јадран и потом, блиске политичке, трговинске и културно-цивилизацијске односе између јадранских обала.

Први период односи се на прве контакте и почетак суживота романског и словенског становништва на подручју Јадрана и укључује касније славизирање мањинског романског становништва. ${ }^{3}$

До другог периода долази са ширењем моћи Млетачке републике почевши од XIII в. и он подразумева млетачку власт над већим делом Приморја, која је трајала све до пада Републике у XVIII в. (в. Мијушковић 1985: 23), као и привредно-трговинску сарадњу и заједничко учествовање континенталног дела Црне Горе са Млецима у ратовима против Османског царства, нпр. Кандијском и Морејском у XVIII в. (в. Станојевић 1953, 1959).

\section{Анализа корпуса}

Блиски и дуготрајни односи између Црне Горе и Апенинског полуострва утицали су на постојање обиља лексике романског порекла присутне како у приморским тако и у говорима залеђа. Бројност романизама у говорима Приморја је очекивана, док је до продора романског утицаја у залеђе дошло на два начина, посредно, преко Приморја и непосредно, директним контактима између Црногораца и Млетака. Непосредни контакт био је, пре свега, привредно-трговински. Млечани су увозили из црногорског залеђа руду, посебно сребро, а увозили тканине (в. Маликовић 2006: 47). Такође, директни контакти укључивали су заједничке војне интересе, који су се огледали у војним подухватима Црногораца и Млечана у ратовима против Османског царства, нпр. Морејски и Кандијски у XVIII в. Ова чињеница имаће значајан утицај на лексику народних говора Црне Горе, што ће наша анализа показати.

Ранија истраживања семантичког аспекта романских позајмљеница дала су почетне резултате које је сада било потребно продубити, првенствено имајући у виду проширење корпуса на говоре приморске и континенталне Црне Горе.

\footnotetext{
${ }^{3}$ Детаљније о насељавању Словена на Јадран и њиховом суживоту са романским становништвом в. Јиречек 1962.
} 
Након ексцерпције грађе, романизми су распоређени у 21 лексичко-семантичку групу. Оне су формиране имајући у виду Баков списак семантичких поља (в. Бак 1949), уз измене које је захтевала специфичност анализираног дијалекатског материјала. На прецизно одређивање лексичко-семантичких група утицала су и наша претходна истраживања семантичког аспекта романизама у појединачним говорима Црне Горе (в. Тешић 2014а, Тешић 2014б). Изван нашег захвата остала је топономастичка грађа која захтева посебан приступ и којој ће пажња бити посвећена у засебној студији.

У раду неће бити наведени сви анализирани романизми и њихови фонетски варијетети, имајући у виду обим нашег корпуса, већ ће бити наведени илустративни примери за сваку од лексичко-семантичких група. Романизми ће бити дати у облику у ком би били наведени као наслови одреднице етимолошког речника романизама, дакле без ознаке за акценат и дужину. ${ }^{4}$ У оквиру анализе лексичко-семантичких група осврнућемо се на резултате који су проистекли из овакве поделе романизама из народних говора Црне Горе.

\section{1. Кућа и покућство}

банак „клупа”, бићерин „већа стаклена чаша”, ваган „здела, чинија”, камара „соба”, кужина „кухиња (обично летња)”, мајелика „бокасти земљани суд за вино и воду, крчаг”, мишћело „већи метални или дрвени суд за прање”, мобиље „намештај”, портик „ходник, трем”, ћикара „шољица”, фрутијера „посуда за воће”, џардин „врт”, шпунга „спужва, сунђер” итд.

\section{2. Одећа и обућа}

абит „врста женске хаљине”, брагеше „дуге гаће оплетене од вуне”, велада „свечани огртач”, камижот „кошуља”, мантељ „капут”, пелица „крзно”, фањела „џемпер”, шупа „сукња”, шал „шал” итд.

\section{3. Накит и козметика}

бразлетна „наруквица, гривна”, кадена „ланац, најчешће за сат”, манина „наруквица”, оћале „наочаре”, фјок ,машна”, фркадела „укосница” итд.

\section{4. Исхрана}

беванда „пиће, најчешће мешавина белог вина и воде”, бешкот „двопек”, кастрадина „кастрадина”, маренда „ужина”, палента „каша скувана од кукурузног брашна”, певер „бибер”, скоранца „осушена укљева из Скадарског језера”, фета „парче, најчешће хлеба”, фундаћ „талог од кафе”, цукар „шећер”, шпира „лоша ракија” итд.

\section{5. Занимања, алати, оружје, материјали}

броква „ексер”, гарабин „карабин, кратка пушка”, гурла „гурла”, ластра „лим, плех”, марагун „зидар”, мацола „врста чекића”, машкуљ „прангија”, орма „коњска опрема”, пала „лопата”, рашпа „дуга и широка турпија за дрво”, фој „лист”, чавао „ексер”, шегац „мала тестера с једном ручком”, штук „кит, четка” итд.

\footnotetext{
${ }^{4}$ На овај начин следи се приступ који примењују аутори Етимолошког речника српског јези$\kappa a$, у оквиру чијег пројекта је написан овај рад. Одлучили смо се за овакво презентовање грађе имајући у виду чињеницу да је велики број романизама посведочен у више фонетских варијаната, што би умногоме утицало на обим рада.
} 


\section{6. Друштвено уређење}

баталеон „батаљон”, брегадир „високи војни чин у староцрногорској војсци”, вера „бурма”, гвардија „стражар”, дација „порез”, жандар „жандарм”, кастио „замак”, киљан „граница, међа”, мацакан „шинтер”, пасапорат „пасош”, пржун „затвор”, фортица „тврђава”, шпедат „болница” итд.

\section{7. Друштвени живот и међуљудски односи}

брушкет „коцка, жреб”, кажин ,„авна кућа”, машкара „маска; маскирана особа, забављач”, фешта „прослава, забава”, шока „шала” итд.

\section{8. Трговина, мере, новац, бројеви}

багатела „ниска цена”, дузина „туце”, капара „предујам”, конат „рачун”, лумер „број”, напулијон „некадашњи златни новац, златник”, ресто „кусур”, сете „седам”, солад „новчана јединица из периода пре Првог светског рата; новац мале вредности”, талијер „врста сребрног новца”, унча „стара мера за дужину и тежину”, фијурин „златник”, цекин „некадашњи млетачки златник, дукат” итд.

\section{9. Биљке и земљорадња}

баланцан „патлиџан”, биџ „грашак”, вердура „поврће”, гарофан „каранфил”, мурва „дуд и плод дуда”, пипун „диња”, помидора „парадајз”, фрут „плод”, циквантин „врста ситног кукуруза" итд.

\section{0. Животиње и сточарство}

бакалај „врста морске рибе, бакалар”, бекацин „врста птице, барска шљука”, бутарга „икра”, кимак „стеница”, кубла „врста рибе” итд.

\section{1. Човек}

бастадур „одважна, храбра особа”, берекин „обешењак, спадало”, галиот „рђав човек, нитков”, марагун „спретан, способан човек”, мацакан „шаљивџија, обешењак”, факин „мангуп, неваљалац”, фарабут „скитница, пропалица”, шимија „оштра, зла женска особа”, штрига „пргава, љута женска особа” итд.

\section{2. Осећањ $а$}

алаграменто „весело”.

\section{3. Сродство и родбински односи}

дондо ,ујак”, кумпар „кум”, фамеља „породица, обично ужа”.

\section{4. Религија и обичаји}

корота „ношење црнине, уздржавање од певања, весеља у знак жалости”, прокарадур „некадашњи црквени тутор”, штрига „вештица”.

\section{5. Медицина, народни лекови, ветерина}

буганци „промрзлине (на ногама)”, маћа „пламењача”, медижина „лек”, фебра „грозница”, фрус „болест коже, мале богиње” итд. 


\section{6. Природа и метеорологија}

арија „ваздух”, бура „североисточни ветар на Јадрану; влага, влажност; невреме”, леванат „источни ветар”, лембо „пљусак”, маштрал „пријатни летњи ветар, маестрал”, шијун „ветар са кишом”, шилок „ветар који дува с мора и доноси кишу; јак пљусак” итд.

\section{7. Бoje}

колур „боја”, шкур ,,таман”.

18. Време и календар

марач „март”, стађун „годишње доба”, ура „сат, час”.

19. Кретање, простор, превозна средства

алабанда „са стране, постраначке”, вапор „брод, пароброд”, вијађ „пут”, дрето „право”, ђир „шетња по вољи”, ђита „излет”, калешин „фијакер са два точка”, кароца „кочија”, трабакула „дрвени бродић за преношење терета; стари камион, аутобус; крнтија" итд.

\section{0. Глас и ономатопеја}

мутат „муцати; неразговетно говорити”, Һакарат „непрекидно причати”, ћакулат „галамити; оговарати”, ћето ,јасно, одрешито (о говору)”, шушур „шапат”.

\section{1. Ономастика}

Бокез „назив за становнике Боке Которске”.

У оквиру семантичке анализе позајмљеница романског порекла разматрано је преко 600 лексема, од којих већина са различитим фонетским варијететима у зависности од народних говора Црне Горе у коме су посведочене.

Лексичко-семантичка група у којој је заступљен највећи број романизама из нашег корпуса (преко 100 речи) јесте поље Кућа и покућство. У овој групи налазе се лексеме којима се означавају делови куће, окућница, покућство. У питању су реалије из свакодневног живота без којих се не може замислити функционисање домаћинства. Најзаступљенији су називи за различите врсте посуда и чаша, нпр. бићерин „већа стаклена чаша”, ваган „здела, чинија”, мајелика „бокасти земљани суд за вино и воду, крчаг”, мишћело „већи метални или дрвени суд за прање” итд.

Велики је број назива који спадају у домен војне терминологије, што не изненађује, имајући у виду заједничке војне интересе и подухвате Црне Горе и Млетачке републике, пре свега у XVIII в. Они су распоређени у групе Друитвено уређење и Занимања, алати, оружје, материјали. Налазе се у две лексичко-семантичке групе јер, иако на ширем плану чине део војне терминологије, на ужем и у оквиру нашег истраживања и поделе, они су део различитих свакодневних активности и области друштвеног деловања. Тако су у групу Друштвено уређење распоређени називи који се везују за војне активности и царину, нпр. баталеон „батаљон”, брегадир „високи војни чин у староцрногорској војсци”, док су у лексичко-семантичку групу Занимања, 
алати, оружје, материјали смештени различити називи за оружје, нпр. гарабин „карабин, кратка пушка”.

Лексичко-семантичка група у којој се такође налази већи број романизама јесте Одећа $и$ обућа. Заступљеност речи у овој групи може се тумачити тесним привредно-трговинским везама не само двеју обала већ и њиховим везама са унутрашњошћу Црне Горе. Оне су укључивале увоз и извоз материјала и робе између Апенинског полуострва, пре свега између Млетачке републике и Старе Црне Горе, с тим што се најинтензивнија размена одвијала у приморским градовима, првенствено Котору и Бару. Ова група речи, укључујући и кулинарску терминологију, распоређену у лексичко-семантичку групу Исхрана, чини значајан део романског наслеђа у говорима не само Црне Горе, већ Јадрана уопште.

Блиске трговинске и привредне везе утицале су и на постојање већег броја романских позајмљеница у области привреде. Ови романизми смештени су у групу Трговина, мере, новац, бројеви. Најчешће су оне романске позајмљенице којима се означавају различите новчане јединице које су кроз историју биле у оптицају, нпр. напулијон „некадашњи златни новац, златник”, солад „новчана јединица из периода пре Првог светског рата; новац мале вредности”, талијер „врста сребрног новца”, фијурин „златник”, цекин „некадашњи млетачки златник, дукат”.

Неке од анализираних романизама није било могуће распоредити у само једну лексичко-семантичку групу. То је најчешће случај са речима високог степена адаптације које су ушле у лексички систем датих говора и развиле вишезначност и породице речи. Вишезначност је главни фактор распоређивања једне речи у више група. Такав је случај романизма марагун који је у народним говорима Црне Горе развио два значења. Прво значење, „столар”, јесте основно значење венецијанског етимона marangon (Мусић 1972: 186; Липовац Радуловић 1981: 208), те се лексема смешта у групу Занимаға, алати, оружје, материјали. Остала значења, специфична за говоре континенталне Црне Горе, јесу „способан, спретан човек” и „спадало, мангуп”, те се стога лексема налази и у пољу Човек. Још један од романизама распоређених у две лексичко-семантичке групе јесте лексема штрига. Романизам је широко распрострањен у народним говорима Црне Горе са два потврђена значења - „вештица”, „пргава, љута женска особа”. Прво значење „вештица” одговара значењу романског предлошка, далмато-романског лексичког остатка од латинског STRĬGA(м) (Лигорио 2014, са прегледом старије литературе) и сврстава га у лексичко-семантичку групу Религија и обичаји. Лексема у значењу „пргава, љута женска особа”, које се развило у народним говорима Црне Горе, налази се у групи Човек.

Битно је напоменути да, иако се најчешће речима романског порекла обележавају нове реалије, њима се такође некад означавају већ постојеће, што би значило да су у употреби у народним говорима Црне Горе упоредо са домаћим речима. Такав је случај, на пример, са речима којима се означавају родбински односи као што су фамеља „породица, обично ужа”, дондо „ујак” итд. Када су у употреби истовремено и реч страног и домаћег порекла често је приметно сужавање, односно специјализација значења било домаће, било стране речи. У 
овим случајевима алоглотска лексика може бити експресивно обележена, нпр. дондо, која се чешће употребљава у хипокористичном значењу, док су друге, попут фамеља, неутралне, али често уже специјализоване.

Имајући у виду блиске и дуготрајне односе двеју обала Јадрана јасно је да су они морали утицати на свакодневни живот становништва Црне Горе. Са доласком нових реалија из области материјалне и нематеријалне културе неумитно су се јављали и нови називи за њих, који су првенствено били примани из италијанског језика и његових дијалеката с којима су српско-хрватски говори били у контакту.

Разлога за то је више. У односу на друге културе и језике, пре свега влашки и албански, који су заступљени на одређеним просторима Црне Горе, италијански одликује културолошки примат, што је и један од основних мотива примања већег броја речи из овог језика и његових дијалеката у односу на друге. Влашки и албански оставили су, стога, своје трагове, пре свега, у топонимији. Влашки и албански елемент видљиви су у оним деловима Црне Горе где су додири становништва били најзаступљенији, уз неколико разлика - албански утицај је просторно ограниченији, има карактер адстрата и узајамна асимилација је била ограниченог домашаја (в. Пижурица 1984: 85). Кучка топонимија показује елементе оба језика - влашки слој у називима Влања, Влање, Влањишта, Влашка гора, Влашки брод (в. Петровић 1988: 13), а албански нпр. у називу географских термина Бигезе, Гура, Шкомб итд. (1.c. 10).

\section{Закључак}

Анализа је показала да је у народним говорима Црне Горе и даље у употреби велики број романизама који су присутни у готово свим сферама свакодневног живота. Њихова употреба је најживља у оним пољима у којима је однос између Црне Горе и Италије био најдужи и најтешњи, као што су трговина и војна сарадња, те отуд велики број назива за кућне предмете, исхрану, различите занате, војне предмете и чинове, мере и новац.

Даље истраживање укључивало би испитивање дубље семантичке раслојености појединачних речи романског порекла са високим степеном адаптације, творбеном продуктивношћу и способношћу развијања полисемије како би се утврдило у којој су се мери оне усталиле као стабилан део српско-хрватског језичког система.

\section{ИЗВОРИ И ЛИТЕРАТУРА}

Бак 1949: C. D. Buck, A Dictionary of Selected Synonyms in the Principal IndoEuropean Languages: A contribution to the History of Ideas, Chicago: University of Chicago Press.

Башановић Чечовић 2010: Ј. Башановић-Чечовић, Рјечник говора Зете, Подгорица: Институт за језик и књижевност „Петар II Петровић Његош”. 
Боричић 2002: В. Боричић Тиврански, Рјечник васојевићког говора, Београд: Просвета.

Вујичић 1995: М. Вујичић, Рјечник говора Прошћења (код Мојковияа), Подгорица: Црногорска академија наука и умјетности.

Вукмановић Мојсиловић 1994: Б. Вукмановић-Мојсиловић, О неким семантичким променама у романизмима црногорског залеђа, Зборник Матице српске за филологију и лингвистику, XXXVII, 157-166.

Гаговић 2004: С. Гаговић, Из лексике Пиве (село Безује), СДЗб 51, 1-312.

Гачић 2008: J. Gačić, Riječi latinskog i romanskog podrijetla u gastronomskoj terminologiji Dalmacije, Filologija, 49, Zagreb, 51-63.

Драшковић 1977: В. Драшковић, О значењу неких романизама у Црној Гори, Научни састанак слависта у Вукове дане, 6/1, 317-330.

Ђоковић 2010: Љ. Ђоковић, Рјечник никиићког краја, Подгорица: Црногорска академија наука и умјетности (Посебна издања ЦАНУ књ. 29, Одјељење умјетности књ. 6).

Јиречек 1962: К. Јиречек, Романи у градовима Далмачије током средњег века, Зборник Константина Јиречека II, Београд: Српска академија наука и уметности.

Јокић 2012: B. Jokić, Rječnik veličkoga govora, Podgorica: Institut za crnogorski jezik i književnost.

Клајн 1998: И. Клајн, Врсте романизама у савременом српскохрватском језику и путеви њиховог доласка, Зборник Матице српске за филологију и лингвистику, XLI/1, 69-89.

Копривица 2006: Ј. Копривица, Речник говора Бањана, Грахова и Опутних $P y \partial u н а$, Подгорица: Црногорска академија наука и умјетности.

Лигорио 2014: O. Ligorio, Problem leksičke stratifikacije u adrijatistici (Nepublikovana doktorska disertacija), Zadar: Sveučilište u Zadru.

Липовац Радуловић 1981: V. Lipovac-Radulović, Romanizmi u Crnoj Gori. Jugoistočni dio Boke Kotorske, Cetinje-Titograd: Obod-Pobjeda.

Липовац Радуловић 1997: V. Lipovac-Radulović, Romanizmi u Crnoj Gori. Budva i Paštrovići, Novi Sad: MBM-plas.

Мијушковић 1985: С. Мијушковић, Историјске везе Црне Горе и Боке Боторске, Бока, Зборник радова из науке, културе и умјетности, 17, Херцег Нови, 21-30.

Милетић 1940: Б. Милетић, Црмнички говор, СДЗб 9.

Мусић 1972: S. Musić, Romanizmi u severo-zapadnoj Boki Kotorskoj, Beograd: Filološki fakultet Beogradskog univerziteta.

Оташевић 2012: D. Otašević, Njeguški rječnik, Podgorica: Institut za crnogorski jezik i književnost.

Пешикан 1965: М. Пешикан, Староцрногорски средњокатунски и љешански говори, СДЗб, 15.

Поповић/Петровић 2009: М. Поповић, Д. Петровић, О говору Спича - Грађа, СДЗб, 56, 5-275.

Петровић и др. 2013: Д. Петровић, И. Ћелић, Ј. Капустина, Речник Куча, СДЗб, 60, 1-461. 
Пижурица 1984: M. Pižurica, Tragovi međujezičkih dodira u govorima Crne Gore, Црногорски говори, Резултати досадашњих испитивања и даљи рад на њиховом проучавању, Титоград: Црногорска академија наука и умјетности, 83-96.

Плишко 2009: L. Pliško, Romanizmi u leksemima za dom i posjed u jugozapadnome istarskome ili štakavskome-čakavskome dijalektu, Čakavska rič, 37/1-2, Split, 147-159.

Ристић 2010: Д. Ристић, Рјечник говора околине Мојковия, Подгорица: Институт за језик и књижевност „Петар II Петровић Његош”.

СДЗб 1905-: Српски дијалектолошки зборник, Београд: Српска академија наука и уметности и Институт за српски језик.

Спицијарић 2009: N. Spicijarić, Romanizmi u nazivlju kuhinjskih predmeta u govoru Dubašnice na otoku Krku - etimološka i leksikološka obrada, Fluminensia, 21/1, Rijeka, 7-24.

Станић 1990-1991: М. Станић, Ускочки рјечник 1-2, Београд: Научна књига.

Станојевић 1953: Г. Станојевић, Црна Гора у доба Кандиског рата (16451699), Историски гласник, 1-2, Београд, 3-53.

Станојевић 1959: Г. Станојевић, Односи Венеције са херцеговачким, брдским и црногорским племенима од опсаде Котора 1657. до почетка Морејског рата, Историски часопис, 9-10, Београд, 205-238.

Стијовић 1996: Р. Стијовић, Романизми у говору Васојевића, $y$ : Ј. Планкош (ред.), О лексичким позајмљеницама, Суботица-Београд: Градска библиотека Суботица-Институт за српски језик Српске академије наука и уметности, 279-297.

Текавчић 1976: P. Tekavčić, O kriterijima stratifikacije i regionalne diferencijacije jugoslavenskog romanstva u svjetlu toponomastike, Onomastica Jugoslavica, 6, Zagreb, 35-56.

Тешић 2014a: А. Тешић, Називи романског порекла за одећу, обућу и накит у говору Спича, Савремена проучавања језика и књижевности, Зборник радова са $V$ научног скупа младих филолога Србије, $5 / 1$, Крагујевац: Филолошко-уметнички факултет, 117-125.

Тешић 2014б: А. Тешић, Кухињска и кулинарска терминологија у говору Спича, Контексти, Први међународни интердисциплинарни скуп младих научника друштвених и хуманистичких наука, Зборник радова, 1, Нови Сад: Филозофски факултет, 225-240.

Тешић 2016: А. Тешић, Романизми у народним говорима Старе Црне Горе и Брда (одбрањена докторска дисертација, Београд, Филолошки факултет, Универзитет у Београду).

Ћупић 1977: Д. Ћупић, Говор Бјелопавлића, СДЗб 23, 1-226.

Ћупић Д./Һупић Ж. 1997: Д. Һупић, Ж. Ћупић, Речник говора Загарача, СДЗб, 44.

Xашић 2003: I. Hadžić, Rožajski rječnik. Građa za diferencijalni rječnik narodnog govora rožajskog kraja, Rožaje: Kulturni centar Rožaje. 


\section{Ana Ž. Tešić}

\section{SEMANTIC ANALYSIS OF ROMANCE LOANWORDS FROM THE VERNACULARS} OF MONTENEGRO

\section{Summary}

This paper presents the semantic analysis of Romance loanwords attested in the vernaculars of Montenegro. The analyzed Romance loanwords are placed in 21 lexical-semantic groups. The goal of this research is to show in which spheres of everyday life Romance languages and dialects were most prevalent, as well to detect some of the possible reasons that led to it. 